(2)

OPEN ACCESS

\title{
Recurrence of Graves' disease in the thyroglossal duct after total thyroidectomy
}

\author{
Ricardo Vaz-Pereira ำ , Carlos Santos, Ana Monteiro, João Pinto de Sousa
}

General Surgery, Tras-os-montes and Alto Douro EPE Hospital Center, Vila Real, Portugal

\section{Correspondence to} Dr Ricardo Vaz-Pereira; ricardovazpereira89@gmail.com

Accepted 14 January 2022

\section{SUMMARY}

Graves' disease (GD) due to hyperfunction of thyroglossal duct remnants is rare, but recurrence after total thyroidectomy is even rarer. We present a rare case of a patient with recurrence of $\mathrm{GD}$ in a thyroglossal duct, after total thyroidectomy, who has been treated by Sistrunk procedure. Patients with a history of GD and difficult thyroid function control after total thyroidectomy should be studied to rule out persistent and functional thyroid tissue. In these cases, surgical treatment is an effective option.

\section{BACKGROUND}

Graves' disease (GD) is typically characterised by diffuse goitre, hyperthyroidism and extrathyroidal manifestations, such as exophthalmos and pretibial myxoedema. It is an autoimmune disease caused by the anti-thyroid-stimulating hormone (TSH) receptor autoantibodies (TRAbs) that activate this receptor, stimulating the diffuse growth of the thyroid and the production of thyroid hormones. ${ }^{1}$

There are three therapeutic options: anti-thyroid drugs, radioiodine, and surgery. ${ }^{2}$ The main goal of treatment is to supress thyroid function and prevent the recurrence of thyrotoxicosis. The recurrence rate after total thyroidectomy is practically nil, ${ }^{34}$ and when present, it is mostly iatrogenic (excessive supplementation), due to the persistence of thyroid tissue on the surgical site, or to the existence of functional ectopic thyroid tissue like the persistence of the thyroglossal duct remnants.

The thyroglossal duct tract results from the descent of the thyroid gland during gestation from the foramen cecum to its final position. The tract usually atrophies, but in some patients, remnants of the tract and thyroid tissue may persist. ${ }^{5}$

There are only a few reports of GD due to hyperfunction of thyroglossal duct remnants, and to the best of our knowledge, only three cases of recurrence after total thyroidectomy have been described by searching in PubMed with the MeSH (Medical Subject Headings) terms "graves disease"; "thyroglossal cyst" and "recurrence". ${ }^{6-8}$

We present a rare case of recurrence of GD in a thyroglossal duct, after total thyroidectomy. permitted under CC BY-NC. No commercial re-use. See rights and permissions. Published by BMJ.

To cite: Vaz-Pereira $R$, Santos C, Monteiro A, et al. BMJ Case Rep 2022:15:e248166 doi:10.1136/bcr-2021 248166

\section{CASE PRESENTATION}

A woman in her 50s with the diagnosis of GD of over 25 years, and no other relevant medical history, refused surgery and was treated with antithyroid drugs.

In 2016, the patient accepted surgical treatment and was referred for general surgery consultation.

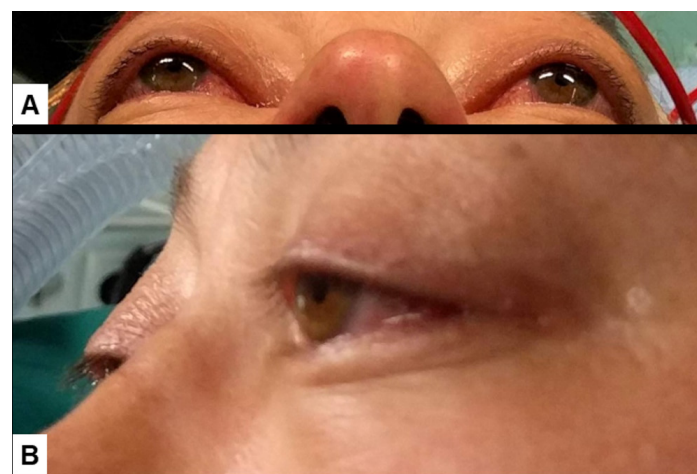

Figure 1 Exophthalmos $(A, B)$.

She presented with diffuse toxic goitre and severe exophthalmos (figure 1). Previous ultrasound and radionuclide scintigraphy confirmed the diagnosis and excluded developmental anomalies. The patient underwent a total thyroidectomy, including the removal of the pyramid lobe and Zuckerkandl tubercles. Pathological examination revealed multinodular hyperplasia compatible with GD. The immediate postoperative period was uneventful and she was treated initially with T4 substitution therapy $(100 \mu \mathrm{g} /$ day $)$. At the end of the first year of follow-up, the patient had persistence of exophthalmos and was persistently hyperthyroid necessitating progressive reduction in levothyroxine dose for supplementation. One year later, she presented with a $3 \mathrm{~cm}$ non-tender cervical midline mass, mobile during swallowing, and protrusion of the tongue, suggestive of a thyroglossal cyst (figure 2).

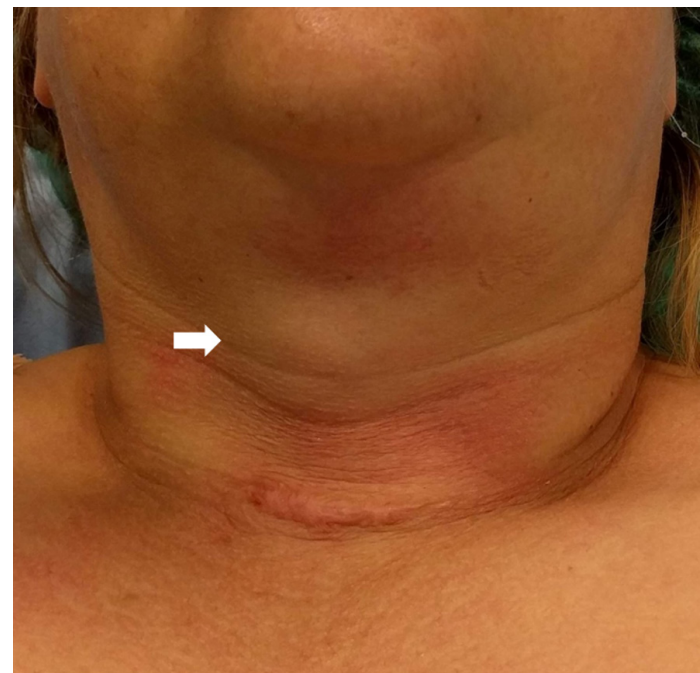

Figure 2 Cervical midline mass (arrow). 


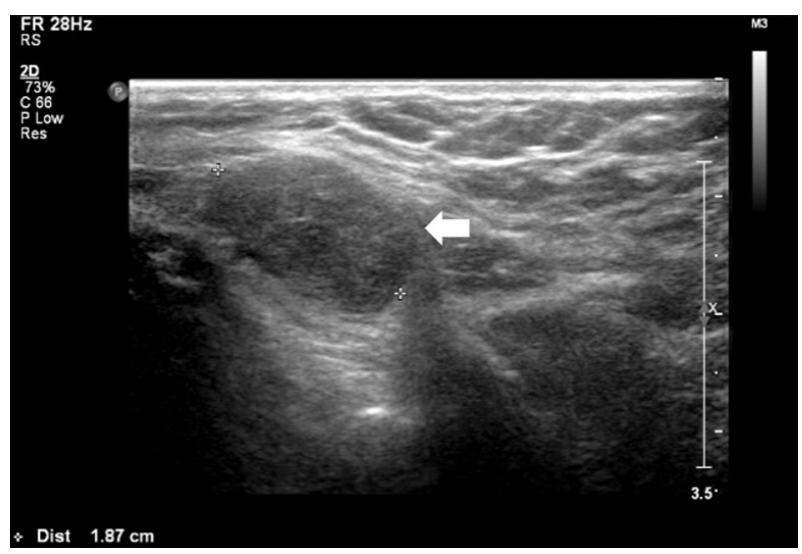

Figure 3 Neck ultrasonography, demonstrating a well-circumscribed rounded nodule (arrow) of mixed echogenicity, approximately $18 \times 16$ $\mathrm{mm}$.

\section{INVESTIGATIONS}

Neck ultrasonography (figure 3) showed an elongated configuration image, of mixed echogenicity and approximately $18 \times 16$ $\mathrm{mm}$. Technetium (99m-TC) thyroid scintigraphy (figure 4) revealed functioning thyroid tissue superior to the thyroid bed, slightly to the right of the midline. TRAbs were increased by about 10 times the normal limit $(17.8 \mathrm{U} / \mathrm{L})$.

\section{TREATMENT}

The euthyroid state was achieved under levothyroxine $50 \mu \mathrm{g} /$ day and the patient underwent an uneventful Sistrunk procedure (figure 5). During the operation, a mass connected to the hyoid bone was identified.

\section{OUTCOME AND FOLLOW-UP}

The histological examination of the specimen (figure 6) revealed ectopic thyroid tissue $(6 \mathrm{~g}$ and $4 \times 2 \times 1.5 \mathrm{~cm}$ ), in the thyroglossal duct, with hyperplasia and lymphocytic infiltrate, compatible with GD, without evidence of malignant involvement. Three years later, the patient continues to be clinically and biochemically euthyroid at a dose of levothyroxine at $100 \mu \mathrm{g} / \mathrm{day}$.

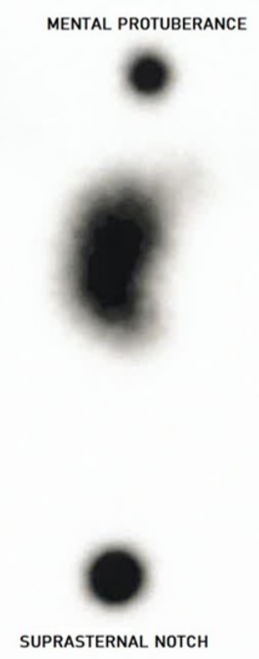

Figure 4 Technetium (99m-TC) thyroid scintigraphy, showing homogeneous uptake thyroid tissue superior to the thyroid bed, slightly to the right of the midline.
However, due to persistence of exophthalmos, tocilizumab was initiated with significant improvement.

\section{DISCUSSION}

Hyperfunction of thyroglossal duct remnants is rare, and relapse of GD by hyperfunctioning ectopic thyroid tissue derived from the thyroglossal duct after total thyroidectomy is even rarer. Theoretically, traces of thyroid tissue, when present in the thyroglossal duct, are subject to the same effect of TSH and TRAb. This ectopic tissue is potentially susceptible to the same thyroid diseases like tumours and, rarely, hyperfunction. ${ }^{9}$

In the present case, the patient had no symptoms, signs, or other clinical and imaging findings suggestive of a thyroglossal duct remnant containing functional ectopic thyroid tissue before total thyroidectomy. Furthermore, during surgery, all visible thyroid tissue was removed, including the pyramid lobe and Zuckerkandl tubercles. Otherwise, the persistence of thyroid tissue at the thyroid site could be the cause of GD recurrence. It appears that after total thyroidectomy, the ectopic thyroid tissue from the thyroglossal duct became hyperfunctioning and had grown in size stimulated by the presence of TRAb, requiring successively lower doses of levothyroxine. We believe that if the patient was not treated, she would end up in a hyperthyroid state.

In cases of thyrotoxicosis or difficulty in thyroid function control after total thyroidectomy with adequate therapeutic adherence, functional ectopic thyroid tissue or thyroid remnants must be suspected. Whenever functional thyroglossal duct remnants are present, like in this case, patients may present with a visible or palpable cervical midline mass,

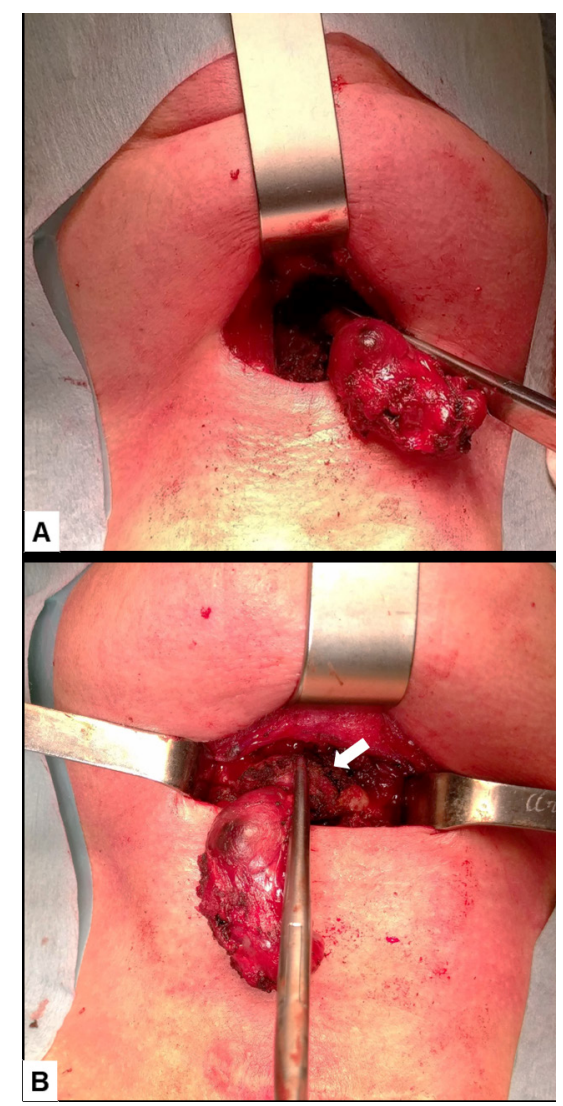

Figure 5 Sistrunk procedure $(A, B)$, during which was observed a mass connected to the hyoid bone (arrow), compatible with thyroglossal duct remnants. 


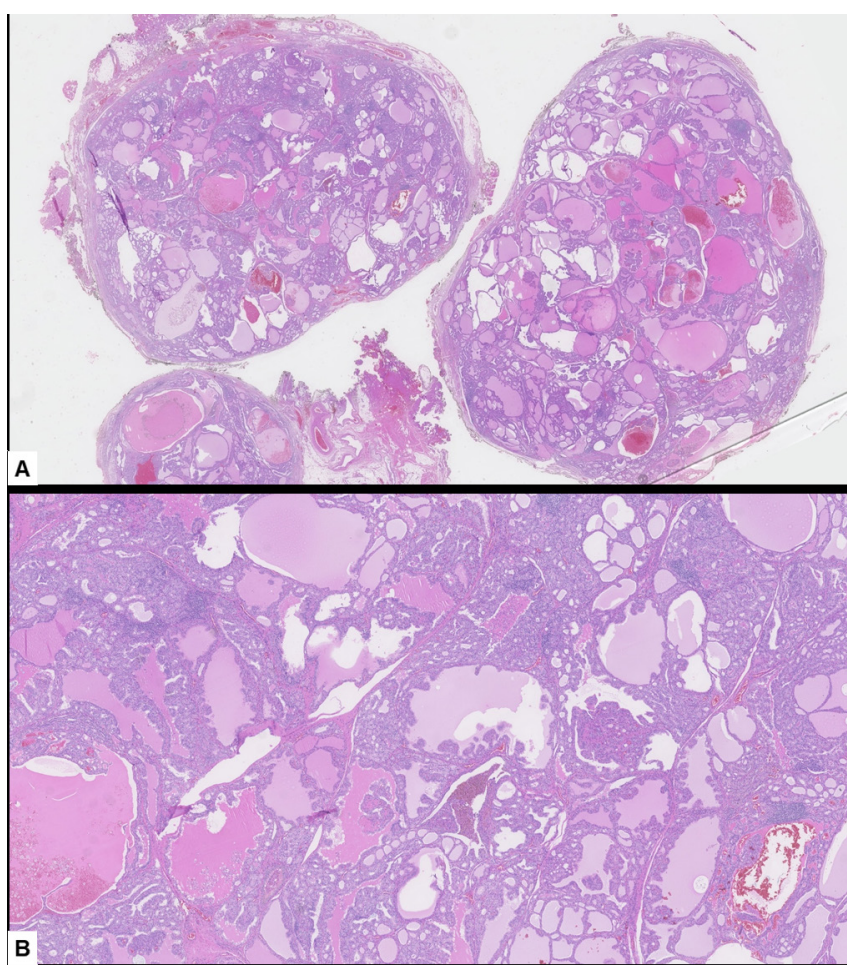

Figure 6 Photomicrographies. H\&E stain lower magnification (A) showing thyroid tissue nodules with multiple dilated follicles, of varying sizes, with colloid. H\&E stain $5 \times$ (B) showing a typical pattern of diffuse hyperplasia with dilated follicles accompanied by papillary hyperplasia. Small interstitial lymphocytic aggregates are also identified.

mobile during swallowing, and protrusion of the tongue. Thyroid scintigraphy with $131 \mathrm{I}$ or technetium is useful for identifying functional thyroid tissue, whereas cervical ultrasound and CT can provide better insight into the location and the relationship with neck structures. Analytically, the patients may present high TRAb levels and an elevated thyroglobulin level, in addition to classic findings of low TSH and high free T4 and T3 concentrations.

Once the diagnosis of functional ectopic thyroid tissue has been established, it is difficult to conclude the best treatment due to the few cases described. Extrapolating from the experience of $\mathrm{GD}$, the same options of treatment are available: anti-thyroid drugs, radioiodine, and surgery. Anti-thyroid agents have the disadvantage of serious adverse effects like agranulocytosis and fulminant liver failure. Radioiodine may worsen the orbitopathy, present in this patient, and surgery

Learning points

- Thyroid tissue present in the thyroglossal duct is potentially susceptible to the same thyroid diseases like tumours and, rarely, hyperfunction.

- Patients with a history of Graves' disease and difficult thyroid function control after total thyroidectomy should be studied to rule out persistent or ectopic functional thyroid tissue.

- Surgery is an effective option to treat functional thyroid tissue in the thyroglossal duct. may be the best option for patients with low surgical risk. The fact that the potential for carcinoma is greater than that of hyperfunction ${ }^{9}$ leads us to believe that surgical treatment should be considered the first line, as was proposed to this patient. It is important that pathology findings must discard functional thyroid cancer metastasis. In the present case, the histological examination of the specimen revealed hyperplasia without malignant involvement, compatible with GD.

On patients with a history of GD and difficult thyroid function control after total thyroidectomy, persistent and functional thyroid tissue should be suspected and verified.

Twitter João Pinto de Sousa @J Pinto-de-Sousa

Contributors RV-P contributed to the conception of this article, reviewed the literature and wrote the manuscript. CS, AM and JPdS had a special contribution to the conception and reviewing of the article.

Funding The authors have not declared a specific grant for this research from any funding agency in the public, commercial or not-for-profit sectors.

Competing interests None declared.

\section{Patient consent for publication Obtained.}

Provenance and peer review Not commissioned; externally peer reviewed.

Open access This is an open access article distributed in accordance with the Creative Commons Attribution Non Commercial (CC BY-NC 4.0) license, which permits others to distribute, remix, adapt, build upon this work non-commercially, and license their derivative works on different terms, provided the original work is properly cited and the use is non-commercial. See: http://creativecommons.org/ licenses/by-nc/4.0/.

Case reports provide a valuable learning resource for the scientific community and can indicate areas of interest for future research. They should not be used in isolation to guide treatment choices or public health policy.

\section{ORCID iDs}

Ricardo Vaz-Pereira http://orcid.org/0000-0003-2348-1655 João Pinto de Sousa http://orcid.org/0000-0001-6634-9756

\section{REFERENCES}

1 Davies TF. Pathogenesis of Graves' disease. In: Ross DS, Mulder JE, eds. UpToDate, 2021. https://www.uptodate.com/contents/pathogenesis-of-graves-disease? search= Pathogenesis \%20of\%20Graves\%27\%20disease\&source=search_result\&selectedTitle= 1 150\&usage_type=default\&display_rank=1

2 Ross DS. Graves' hyperthyroidism in nonpregnant adults: Overview of treatment. In: Cooper DS, Mulder JE, eds. UpToDate, 2020. https://www.uptodate.com/contents/ graves-hyperthyroidism-in-nonpregnant-adults-overview-of-treatment?search= Graves \%27\%20hyperthyroidism\%20in\%20nonpregnant\%20adults:\%200verview\% 20 of\%20treatment\&source $=$ search_result\&selectedTitle $=1 \sim 150 \&$ usage_type $=$ default\&display_rank=1

3 Jakibchuk K, Ali S, Samantray J. Recurrence of Graves' disease in ectopic thyroid tissue. BMJ Case Rep 2018;2018. doi:10.1136/bcr-2017-221566. [Epub ahead of print: 23 Jan 2018].

4 Hussain YS, Hookham JC, Allahabadia A, et al. Epidemiology, management and outcomes of Graves' disease-real life data. Endocrine 2017:56:568-78.

5 Randolph GW, Kamani DV. Thyroglossal duct cysts and ectopic thyroid. In: Carty SE, Ross DS, Chen W, eds. UpToDate, 2020. https://www.uptodate.com/contents/ thyroglossal-duct-cysts-and-ectopic-thyroid?search=Uptodate $\% 20-\% 20$ Thyroglossal\% 20duct $\% 20$ cysts $\% 20$ and\%20ectopic\%20thyroid\&source=search_result\& selectedTitle $=1 \sim 150 \&$ usage_type $=$ default\&display_rank=1

6 Vercher-Conejero JL, Rivas-Sanchez A, Bello-Arqués P, et al. [Recurrence of hyperthyroidism in a female patient with thyroidectomized Grave's disease diagnosed 15 years earlier]. Rev Esp Med Nucl Imagen Mol 2012;31:108-9.

7 Cigrovski-Berković M, Solter D, Solter M. Why does the patient with Graves' disease remain euthyroid/mildly hyperthyroid following total thyroidectomy--the role of thyrotropin receptor antibodies (TRAb) and vestigial remnants of the thyroglossal tract. Acta Clin Croat 2008;47:171-4.

8 Basili G, Andreini R, Romano N, et al. Recurrence of Graves' disease in thyroglossal duct remnants: relapse after total thyroidectomy. Thyroid 2009;19:1427-30.

9 Buckingham H, Sauerwein TJ, Golding AC. Graves' disease in the cervical thyroid and thyroglossal duct remnant: case report and review of literature. Endocr Pract 2006:12:401-5 
Copyright 2022 BMJ Publishing Group. All rights reserved. For permission to reuse any of this content visit https://www.bmj.com/company/products-services/rights-and-licensing/permissions/

BMJ Case Report Fellows may re-use this article for personal use and teaching without any further permission.

Become a Fellow of BMJ Case Reports today and you can:

- Submit as many cases as you like

- Enjoy fast sympathetic peer review and rapid publication of accepted articles

- Access all the published articles

- Re-use any of the published material for personal use and teaching without further permission

Customer Service

If you have any further queries about your subscription, please contact our customer services team on +44 (0) 2071111105 or via email at support@bmj.com.

Visit casereports.bmj.com for more articles like this and to become a Fellow 